\title{
Å sjå røysa som eit objekt, ein markør og ein prosess av handlingsmønster
}

\author{
HÅKAN PETERSSON
}

\begin{abstract}
Petersson, H. 2020. Prehistoric stone cairns as an object, representation and process of change. AmS-Varia 61, 139-154, Stavanger, ISSN 0332-6306, ISBN 978-82-7760-187-8

Cairns: graves, clearances or both, a seminar held at the Museum of Archaeology, University of Stavanger, in February 2017, attempted to look beyond the traditional concept of cairns as objects resulting from specific or single activities, focusing instead on the idea of a more fluid symbolism, constantly changing over time. This article seeks to build upon the questions and themes raised at the seminar, combining traditional definitions of cairns with the results of more recent research. The results will then be discussed in a broader, Scandinavian context. The aim is to draw attention to the idea that cairns are the product of various ongoing processes, both active and symbolic, and that these processes continuously redefine the relevance and meaning of cairns to society. The article will also draw attention to the results of more recent research and the implications they have for the field of cultural heritage management, both administratively and practically, and cultural heritage legislation in general in Norway.
\end{abstract}

Håkan Petersson, Museum of Archaeology, University of Stavanger, N-4036 STAVANGER. NORWAY.

E-mail: hakan.petersson@uis.no

Keywords: farming, grave mounds, clearance cairns

\section{Innleiing}

I denne artikkelen vil eg diskutere den norske forvaltninga sin dikotomi mellom dei to definisjonane av kulturminnekategorien røys; rydningsrøys og gravrøys. Eg vil også drøfte fokuset vårt på å sjå røysa som eit funksjonelt objekt og ikkje som eit meiningsberande handlingsmønster med fleire samtidige intensjonar. Aktuell forsking og teori frå Sverige vil trekkast inn for å nyansere biletet av steinbruken i skandinavisk forhistorie.

Det er også tidlegare blitt påpeikt at graver og rydningsrøyser finst saman, og at skiljet mellom dei kan vere vanskeleg å identifisere, blant anna når opphavlege gravrøyser er omforma og dekka til av rydningsstein. Frå nyare undersøkingar kan vi no òg vise til det motsette. Det har gjennom åra synt seg vanskeleg å lage tydelege definisjonar av røyser utan funn, og funntomme gravrøyser blir difor definerte ut frå oppbygginga og særeigne konstruksjonsdetaljar, samt plasseringa i landskapet.

Det som gjer diskusjonen interessant som tema i denne artikkelen, er at mange gravliknande røyser er anlegg utan grav i form av menneskeleivningar, men dei er konstruerte med eit formspråk og ei omsorg som gjer at vi tolkar dei som graver. Dette har vorte forklara av nyare forsking som at det viktigaste ved å bygge dei, var rituala som ein einskapleg sosial praksis av fortidige handlingar (Wangen, 2009, s. 124-125, 136-137). Undersøkingar av svenske rydningsrøysfelt (Svanberg, 2000, s. 131; Häggström, 2005, s. 65-93, 101-103, 117126, 129-136; Hansson, 2008) viser same parametrar, og difor burde same sosiale praksisar også trekkast fram som moglege aspekt ved bygging av slike felt. Dette tyder på at vi bør vie rydningsrøysområda større interesse. Vi har eksempel frå ulike delar av Skandinavia på heile kompleks av strukturar i røysfelt, der røysene berre er det synlege symbolet på kulturminna. Slike haldningar til tolkingar av materialet er no også styrka av nyare undersøkingar i Rogaland. Dei viser at røysfelt sjeldan berre er ryddingar, eller at graver berre er graver, og at bruken av og brukstida til røyser har ei komplisert historie.

Artikkelen fører desse teoriane vidare og fokuserer på at vi ikkje tek inn over oss konsekvensane av den 
nye kunnskapen i sakshandsaminga. Dette gjeld både ved registreringar og tilrådingar, samt ved formuleringar av problemstillingar, kostnadsberekningar og gjennomføring av undersøkingar.Forvaltninga og forvaltningsarkeologien ser meir til objekta enn til dei kontekstuelle sambanda dei er, eller kan vere, ein del av.

Eg vil i artikkelen argumentere for at ei røys og ulike andre steinkonstruksjonar også har ei meiningsberande tyding visualisert i det fysiske objektet, med for eksempel betyding for næringsstrategi, ideologi, kult eller ritual knytte til fruktbarheit.

I denne samanhengen bør også forvaltninga sitt syn på agrarhistoriske kulturminne og det vi kallar rydningsrøyser, revurderast. Agrarhistoriske kulturminne er kanskje meir enn funksjonelle restprodukt av dyrking, som også kan setjast saman med ein integrert fruktbarheitskult. Er det på tide å sjå dei som resultatet av komplekse relasjonar i høve til andre strukturar og kulturminne i same området (sjå f.eks. Holm, 1995, s. 54-57; Häggström, 2005, 122-126; sjå også Petersson, M., Meling, T. samt Gil Bell \& Denham, denne antologien)?

\section{Stereotypane rydningsrøys versus gravrøys}

Definisjonane av om eit kulturminne er rydding eller grav har i forvaltninga stor påverknad på sakshandsaminga, ikkje minst for kva krav som vert sette til undersøking før frigjeving. Desse definisjonane av røyser er ofte baserte på overflate-karakteristikkar og forhold knytte til utsjånad og plassering. Særleg rydningsrøyser har ein funksjonell objektdefinisjon som ukompliserte resultat av at ein rydda marka for å dyrke. Dette fører gjerne til at ein i undersøkingar fokuser på objektet, snittar det og tek ut prøvar. Undersøkingar viser at ei kontekstuell forståing med kringliggande område, landskap og andre kulturminne kan gi auka informasjon om tydinga til røysene, men også om agrarsamfunna si førestillingsverd og kult, som røysene er ein del av. Kven veit kva som blir resultatet om vi verkeleg byrjar å granske rydningsrøysområde med same ambisjonar som f.eks. gravrøyser, med store undersøkingsareal kor vi ser etter andre strukturar kring og utanfor røysene under dyrka mark.

Plassering i landskapet eller vurderingar ut frå storleik og form er vanlege, men problematiske parameter, når røyser berre er overflateregistrerte og ikkje undersøkte. I forvaltninga har det utvikla seg nokre stereotypar for kva som er ei rydningsrøys, og kva som er ei gravrøys:

- Gravrøyser er tydeleg konstruerte, mens rydningsrøyser har meir karakter av samankasta stein.
- Rydningsrøyser ligg topografisk lågt i terrenget innved rydda flater, mens gravrøyser er antatt å ligge høgt eller markerte i terrenget.

- Steinsamlingar ved markfaste steinblokker og ovale og geometrisk uregelmessige røyser vert gjerne registrerte som rydningsrøyser, mens røyser med rund struktur og med laga kant vert vurderte til å vere graver.

- Små diffuse røyser blir sett på som ryddingar, og store påfallande røyser som graver.

Definisjonar bygde på slike stereotypiske oppfatningar om ein "rett" måte å tolke røyser på, sementerer alt eksisterande haldningar. I dette tilfellet låser dei fast einskilde røyser i tradisjonelle kategoriar og risikerer å skape ulike former for sirkelresonnement. Samstundes hindrar dei fastlåste definisjonane ei endring av tolkingar og etablering av nye typar kulturminne eller eit endra syn på forhistoriske aktivitetar.

Dette blir ikkje betre av at ein førande grunntanke ser ut til å vere at om det ikkje går å klargjere statusen til ei røys, så vert ho klassifisert som ei rydningsrøys. Slik blir 'rydningsrøys' i mangel på andre kategoriar i tillegg ein slags restkategori av det som ikkje kan definerast som grav. Eg meiner at dei seinare åra med undersøkingar frå for eksempel Rogaland, som eg skal kome tilbake til, men også forsking frå andre deler av Skandinavia, tilseier at desse stereotypiske utgangspunkta for definisjon av røyser ikkje held stikk og må revurderast. Likevel verkar dei framleis å liggje til grunn for mykje av registreringsmetodikken og bidreg til å devaluere verdiane av rydningsrøysområde innanfor forvaltninga og kanskje til å feiltolke funntomme, men fint bygde røyser, til graver.

$\AA ̊$ sjå rydningsrøyser som berre eit objekt av stein, eit slags restprodukt frå oppdyrking av mark, skapar ei oppfatning i forvaltninga av at omfang og kostnader ved ei arkeologisk undersøking kan reduserast. Eg meiner at slike oppfatningar ikkje tek omsyn til rydningsrøysfelta si betyding for eit samla forhistorisk samfunnsbilete. Undersøkingar viser at denne typen kulturminne ikkje er det eine eller det andre, men snarare resultat av komplekse prosessar i ein langtidsbruk av landskapet, på ein liknande måte som Barbro Dahl viser at ei grav er ikkje berre ei grav, men ein prosess av hendingar over lang tid (Dahl, 2016). Vi burde difor ta større omsyn til - og leggje større vekt på - agrarhistoriske kulturminne som rydningsrøysfelt ved undersøkingar, om vi vil kome vidare med å forstå dei forhistoriske samfunna og den tydinga agrarleivningar har hatt. Vi vil aldri få svaret på slike spørsmål om vi ikkje byrjar å undersøke alle 


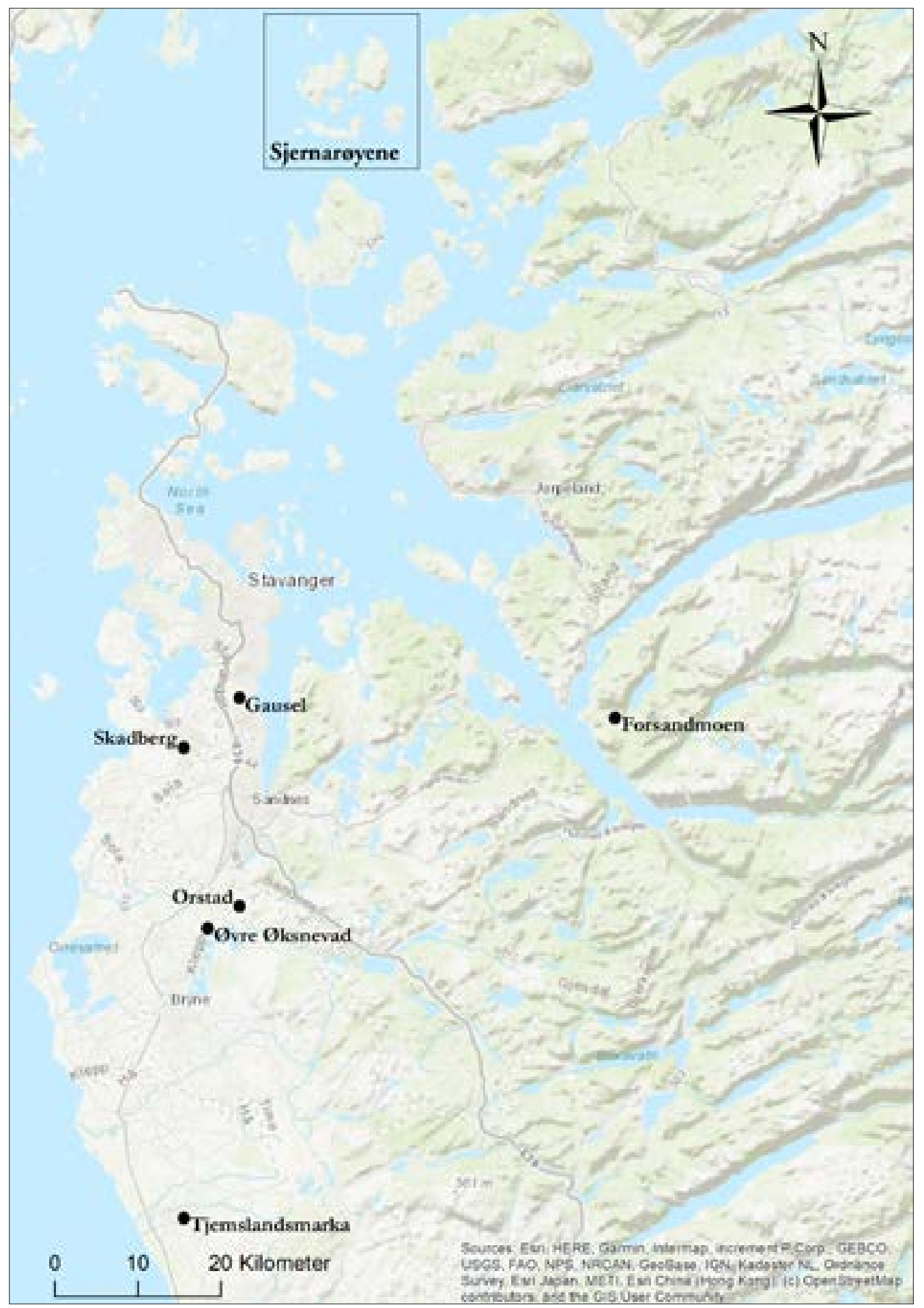

Fig. I. Kart som syner det undersøkte røysområdet på Sjernarøyene, Finnøy samt de øvrige røysfelta frå Rogaland som er nemt i teksten. Kart: Håkan Petersson

Fig. I. Map showing the investigated area with cairns at Sjernarøyane, Finnøy, and the other fields with cairns mentioned in the text that are situated in Rogaland county. Map: Håkan Petersson

typar av røyser med same nøyaktigheit. Å granske ulike typar av røyser med same spesifikke metodikk gong etter gong vil berre sedimentere dei typedefinisjonane vi alt brukar. Røysa som objekt må undersøkast med eit stratigrafisk-metodisk innhald som gjer det mogleg å identifisere anleggstid i relasjon til brukstid, bruksfasar, innhald i bruk, men ho må også sjåast kontekstuelt i kombinasjon med andre typar av strukturar på same plass og andre typar av kulturminne. Det vil seie at vi må opne opp større areal kring røysa og røysfeltet for å forstå kulturminneområdet sin kompleksitet og potensial, slik det er gjort i andre delar av Skandinavia (f.eks. Häggström, 2005; Petersson, 2015).

\section{Å sjå med andre auge}

Eg meiner definisjonane av røyser, men også gravhaugar, er sterkt kategoriske, noko som ikkje minst går fram av registreringane i det nasjonale kulturminneregistret 
(Askeladden). Ut frå dette ville eg difor teste dei tradisjonelle stereotypiske oppfatningane av røyser opp mot kunnskap frå nyare undersøkingar i ein visuell landskapsanalyse. Eg valde Sjernarøyane i Finnøy kommune, i midtre strøk av Ryfylke sitt fjordlandskap (Fig. 1). Grunngjevinga for å velje nettopp Sjernarøyane, og særleg øya Kyrkjøy, var ei blanding av eit velbevart kulturlandskap, det avgrensa området øya utgjer og potensialet som registreringane i det nasjonale kulturminneregisteret viste. Ein annan fordel er at registreringane er utførte av Arkeologisk museum, slik at analysane ikkje kan oppfattast som ein kritikk frå museet si side retta mot andre instansar. Synfaringa vart gjort tidleg om våren då vegetasjonen var låg $\mathrm{og}$ kulturminna synlege. Likevel viste det seg vanskeleg å finne igjen fleire røyser.

Sjernarøyane har eit svært godt bevart kulturlandskap som er lite endra av moderne landbruk. På øyene er det gjort forholdsvis få registreringar ved sjakting, og difor er det kjende kulturmiljøet karakterisert av synlege kulturminne kor dei fleste er overflateregistrerte av museet. Gravmonumenta (haugar og røyser) samt rydningsrøyser er heilt dominerande i kulturlandskapet, der dei største ligg sentralt plasserte kring ein mellomaldersk kyrkjestad (Fig. 2). Det er samstundes, relativt sett, svært få av røysene som er klassifiserte som rydningsrøyser eller rydningsrøysfelt. Med tanke på at ei undersøking utført av Arkeologisk museum, Universitetet i Stavanger, i 2014, viser korleis området har vore dyrka sidan seinneolitikum/bronsealder (Jensen, Ahlquist \& Fredh, 2015) gjev dette eit skeivt bilete. Proporsjonalt sett kan ein anta at det har vore same intensitet $i$ dyrking her som i andre fullåkerlandskap. Kanskje har ikkje intensiteten vore den same som på Jæren, men dei som budde på Kyrkjøy måtte òg rydda stein om det skulle dyrkast.

At det finst relativt få rydningsrøyser på Kyrkjøy, samanlikna med gravrøyser/haugar, er interessant. Ein kan lure på om små uformelege haugar på eit par meter i diameter, ei høgd på 0,5-1 m og med eit fåtal større synlege steinar, ved overflateregistreringa har vorte klassifiserte som gravmonument i forholdsvis større grad enn for eksempel på Jæren. Bevaringsforholda på Kyrkjøy er bra, og øya kan sjåast på som eit sakralt landskap. Dei fleste røysene ligg, i ei eller anna form, markant plasserte i terrenget, der stereotypen tilseier at graver skal liggje. Er det slike inntrykk og forhold som gjer at ikkje kategorien rydningsrøys blir ein restkategori for alt som er utydeleg og usikkert på Sjernarøyane, men i staden vert tolka som graver? Eller har ein på Kyrkjøy brukt den steinen ein ynskte å rydde til å bygge gravmonumenta med? Undersøkingar ved Orstad (Bjørdal \& Rødsdalen, 2015) og Øvre Øksnavad i Klepp kommune (under arbeid, men sjå også Gil Bell \& Denham, denne antologien) indikerer mogelegheit for ein slik kombinert bruk av røyser.

\section{Stereotypar i Sjernarøyane sitt kulturlandskap}

På Sjernarøyane peikar dei sentrale delane av øya Kyrkjøy, kring den gamle kyrkjestaden, seg ut som eit sentralområde, omkransa av graver. Felles for skildringane av kulturminna er:

- Uansett om røysene er utydelege og vanskelege å kjenne igjen, eller om dei står fram som klare, er dei definerte som graver om dei er runde, og som rydningsrøyser om dei er ovale.

- Røyser på berg, uansett monumental effekt og kor synlege dei er, er tolka som graver, også dei som er heilt eller delvis dekte av torv og ikkje lette å finne igjen. Fleire viste seg å vere enno vanskelegare å påvise i dag enn ved registreringa, trass i at områda ikkje er dyrka, men vert brukte til beite.

- Andre runde røyser, plasserte ved ein jordfast stein, er gjerne klassifiserte som rydningsrøyser.

- Små og uklare røyser som er vanskelege å bestemme i form og oppbygging nær den gamle kyrkjestaden, er definerte som graver, mens liknande røyser lengre frå kyrkjestaden er definerte med større usikkerheit eller som rydningsrøyser. Ved feltbesøka mine kunne eg ikkje sjå forskjell på desse røysene og rydningsrøyser etter tradisjonelle definisjonar. Ofte hadde mange av dei som var definerte som graver, stor variasjon i storleiken på stein i overflata. Mange gonger dreidde det seg om mykje store stein.

- Ovale røyser plasserte i overgangen bakke/flate, som det ikkje er særleg mange av, ser (iallfall dei eg har besøkt) ut å vere definerte som rydningsrøyser. Særleg gjeld dette eitt kulturminne (Id. 14538), som eg vil komme tilbake til.

- Mange gonger er røyser som er uklart markerte, men som teiknar seg ut i terrenget, definerte som graver, utan at eg kan sjå anna grunn for karakteristikken enn stereotypien om plasseringa. Fleire er svært vanskelege å finne igjen. Nokre få med nokolunde rund form, plasserte på skråningar, men som teiknar seg mindre tydeleg ut i terrenget, blir også definerte som gravrøyser, men då oftast med tillegget «Kan muligens være noen rydningsstein». 


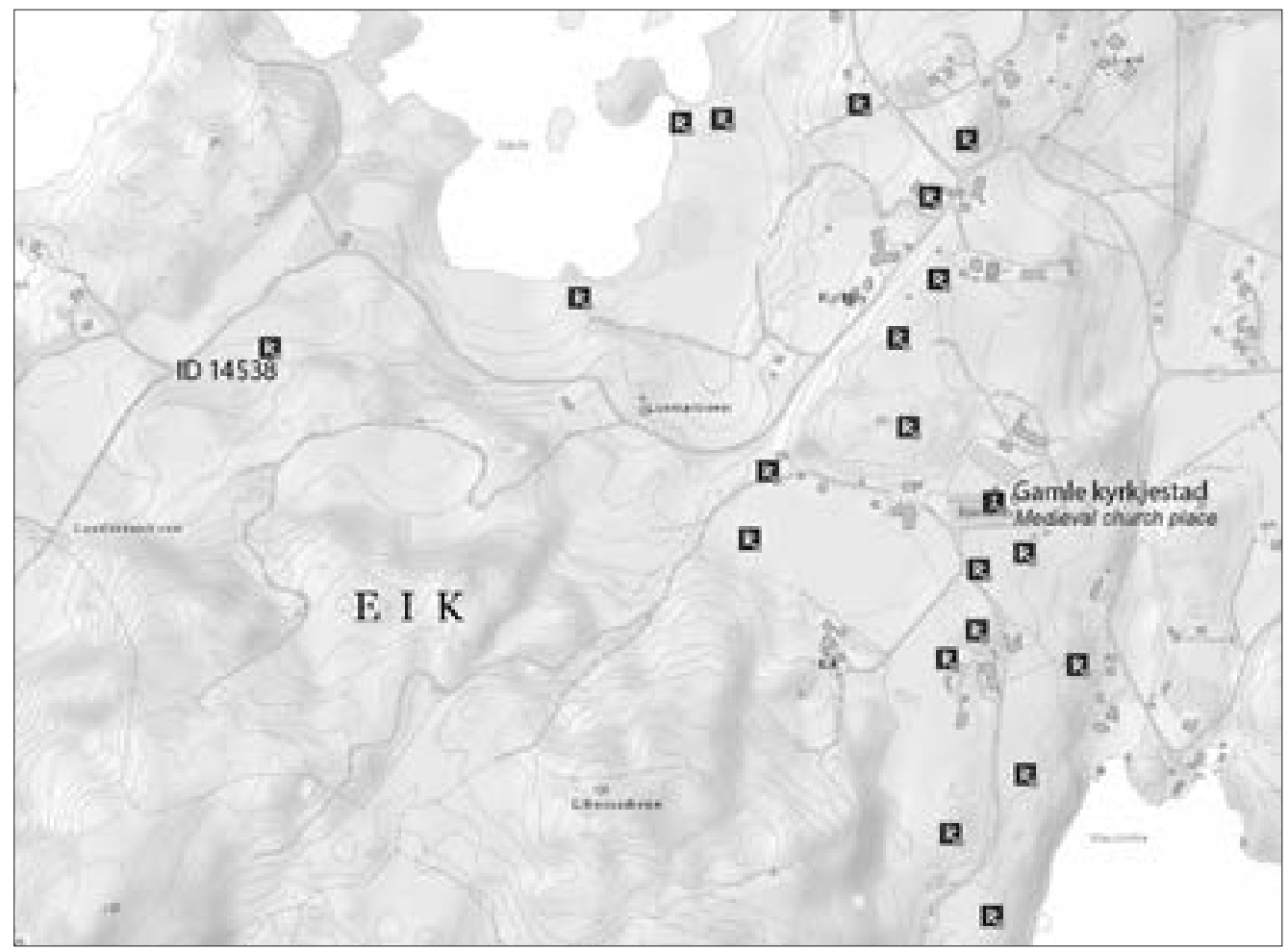

Fig. 2. Kart over dei sentrale delane av Kyrkjøy, Sjernarøyene, med rydningsrøysfelt Id. 14538 i utkanten av det sentrale kulturminneområdet ved den gamle kyrkjestaden. Kart: Håkan Petersson Fig. 2. Map of the central area of Kyrkjøy, Sjernarøyane, with the clearance cairns at site Id. 14538 in the periphery to the major heritage site and the old medieval Church site. Map: Håkan Petersson

Tankegangen om at røyser i hellande terreng er rydningsrøyser, mens røyser på bakketoppar, høgdedrag o.l. er graver, held ikkje stikk på Sjernarøyane eller andre område i Rogaland (f.eks. Bortheim \& Dahl, 2014; Husvegg, Soltvedt \& Dahl, 2017; Bjørdal, denne antologien). Det er vanskeleg å ikkje få utsyn frå ei røys på Kyrkjøy, og dei klassifiserte rydningsrøysene ligg markant plasserte i terrenget med godt utsyn. Mange av dei klassifiserte gravrøysene ligg i rydda og dyrka område, gjerne i kanten av desse, og innimellom i hellingar i terrenget. Det kan dreie seg om ryddingar eller graver, men slike røyser på Kyrkjøy er i det nasjonale kulturminneregisteret klassifiserte som graver.

\section{Rydningsrøysfelt Id. I4538, Kyrkjøy}

Ca. $750 \mathrm{~m}$ vest for kulturminnekonsentrasjonane kring den gamle kyrkjestaden ligg rydningsrøysfeltet Id. 14538 som einaste kulturminne (Fig. 2). Det inneheld tolv røyser, alle definerte som rydningsrøyser. Feltet ligg i beitemark i ei svak skråning med eit høgare skogkledd berg i sør. I nord finst eit våtmarksområde. Ser ein vekk frå skogen, er det godt utsyn til sjøen. Alle røyser på Id. 14538 er klart markerte i terrenget. Dei fem-seks vestlegaste ligg på ein liten avsats i skråninga. Fleire av rydningsrøysene har truleg hatt kantkjeder, mens andre er meir varierte på overflata, men likevel med ei distinkt avgrensing. Fleire av dei kan definerast som runde heller enn ovale. Lengre i aust blir området eit meir diffust samanhengande belte av stein (Fig. 3).
Dei første fem-seks røysene i den vestlege delen av feltet kan sikkert vere gravrøyser, men frå andre område veit vi at også rydningsrøyser kan vere strukturert bygde opp og tydeleg organiserte (Häggström, 2007, s. 34, 2005, s. 102-103, 125; Lönn, denne antologien). Nokre av røysene i dei sentrale delane av feltet er meir usikre. I relasjon til andre definerte gravrøyser på øya kunne dei vere graver, men ut frå dei tradisjonelle kriteria for kva som er ei gravrøys og ei rydningsrøys, bør dei sjåast som rydningsstein. Dette kan ikkje avgjerast utan undersøking. Dei ligg likevel inntil eit rydda område, så steinane har etter alt å døme vorte fjerna frå flata. Desse observasjonane gjev grunnlag for fleire spørsmål. Er dei utydelege røysene opphavleg graver, der folk seinare har lagt på rydningsstein, som har bidrege til at dei ikkje ser like strukturerte ut som dei meir tydelege røysene? Eller har større vekst av humus, kanskje frå erosjon i det hellande terrenget på denne staden, gjort røysene meir utydelege? Ifølgje rapportar frå forvaltningsgravingar i ulike delar av Skandinavia er det ikkje uvanleg at røyser som er utydelege på overflata med eit variert steinmateriale og uklare ytterkantar, viser seg å vere graver etter at torva er fjerna (f.eks. Dommasnes, 1997, s. 104; Lönn, denne antologien).

Eg vil tru at avstanden frå det dominerande gravrøysmiljøet ved den gamle kyrkjestaden og plasseringa nedanfor eit berg i eit område som ser ut til å ha vore rydda, heller enn strukturelle definisjonar av ulike typar røyser, har vore avgjerande for at feltet Id. 14538 er 

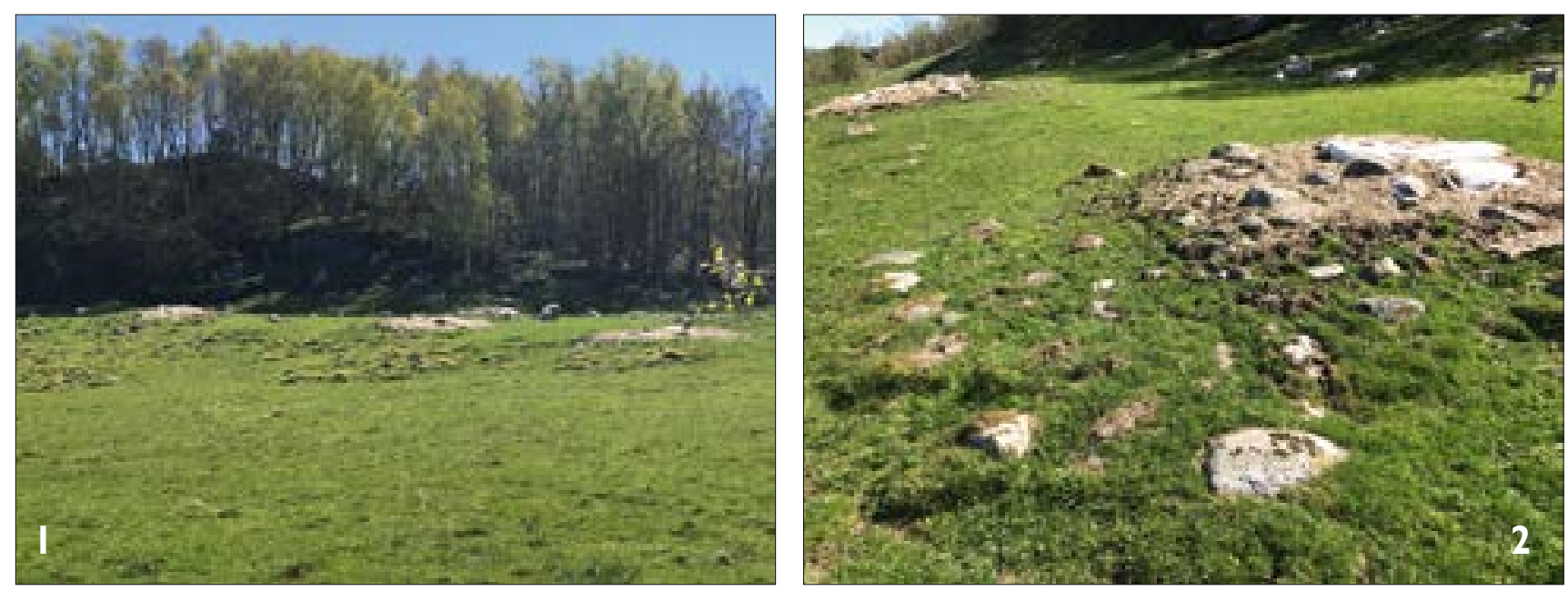

Fig. 3. Foto av røysene på Id. 14538.

I. Den sentrale delen av røysfeltet sett frå nordvest.

2. Detalj av ei røys med mogleg kantkjede.

3. Detalj av ei røys frå feltet sin vestlege del. Foto: Håkan Petersson

Fig. 3. The cairns at Id. 14538:

I. The central part of the field seen from the northwest,

2. Close-up of a cairn with possible kerb-stones;

3. Detail from one of the cairns in the western part of the site. Photo: Håkan Petersson

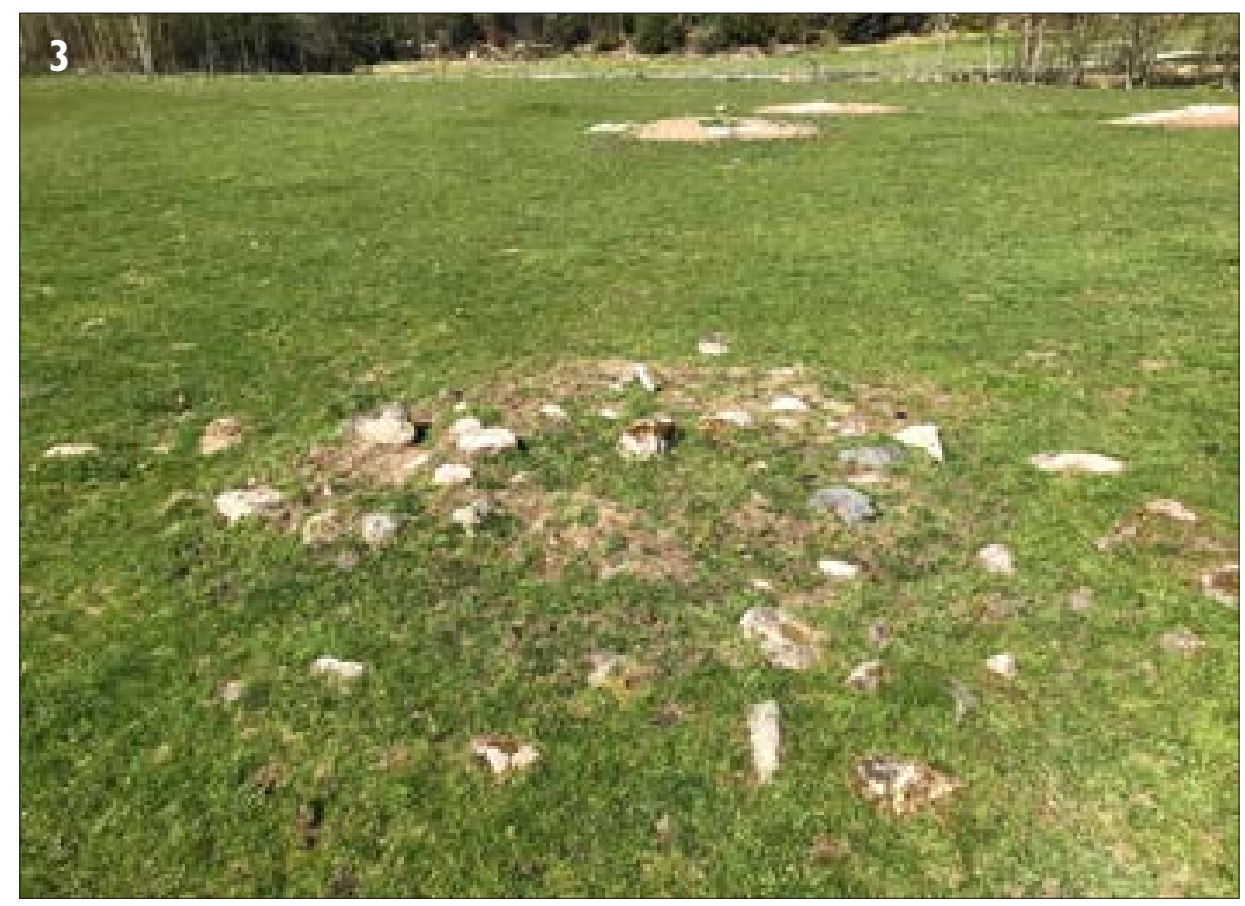

definert som rydningsrøyser. Men som nemnt tidlegare, har området - om vi ser vekk frå skogen - ei plassering med utsyn mot sjøen og mot andre høgdedrag med klassifiserte gravrøyser.

Samstundes finst eit par røyser direkte nord for sentralområdet ved den gamle kyrkjestaden og det store gravfeltet (Id. 14539, Fig. 4), som har fleire likskapstrekk med røysene på Id. 14538. Dei ligg også på kanten av eit høgdedrag og i kanten av dyrka mark, som utgjer skråninga nord for gravfelt Id. 14539. Plasseringa innved dyrka mark i svak skråning er som for Id. 14538, men desse to røysene ligg høgare i terrenget. Begge røysene, Id. 56375 og Id. 4734, som manifesterer seg ved nokre store steinar på berg, liknar dei diffuse røysene på Id. 14538, men er klassifiserte som graver. Det er heilt klart at plasseringa i landskapet må ha vore avgjerande for definisjonen og ikkje røysene si fysiske framtoning.
Andre klassifiserte rydningsrøyser på Kyrkjøy (for eksempel Id. 53981 og Id. 71897) har ei monumental plassering. Særleg Id. 53981 ligg høgt opp på eit berg i eit område som kan vere rydda, og med utsyn over heile Sjernarøyane og langt inn i fjellområda i indre Ryfylke (Fig. 4). Id. 71897, så langt det er mogleg å finne dette kulturminnet att, ser meir ut som ei rektangulær røys, plassert oppe på eit berg med vidt utsyn (Fig. 5A). Om lag $50 \mathrm{~m}$ sør for røysa, på den same 15-20 m høge bergknausen med dyrka mark nedanfor, ligg ei liknande rund forhøging i terrenget, klassifisert som ein rundhaug (Id. 44239) (Fig. 5B). Kring $100 \mathrm{~m}$ aust for desse, nedanfor høgda, finst ei samling av stein på berg innved dyrka mark definert som ei grav, men kor ingen av dei tradisjonelle kriteria, eller resultat frå nyare undersøkingar, motseier at dette kan vere ei samling rydningsstein (Id. 34199) (Fig. 5C). 


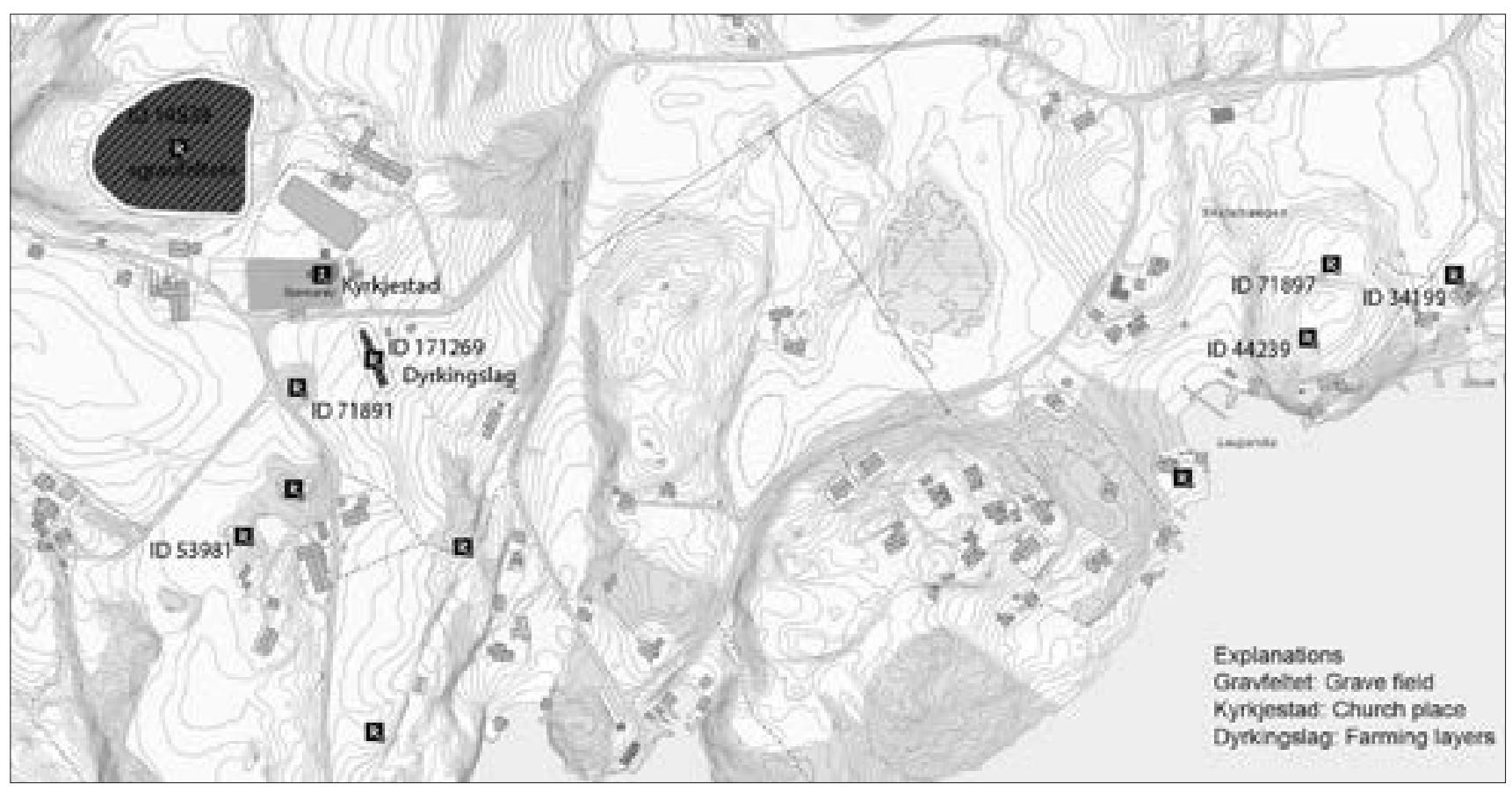

Fig. 4. Kart over sentrale delar av Kyrkøy med det store gravfeltet (Id. 14539), området med undersøking av dyrkingslag (Id. I7I269) og eit par andre namngjevne lokalitetar markerte. Kart: Håkan Petersson

Fig. 4. Map of the central area of Kyrkøy with its medieval church site and large, central prehistoric grave field (Id. 14539,) together with excavated farming layers (Id. 17/269) and other sites mentioned in the text. Map: Håkan Petersson

Andre gravrøyser (Id. 53981, 71891) sør for den gamle kyrkjestaden på Kyrkjøy ligg ikkje meir markant enn .i nemnte rydningsrøysene (Fig. 5). Den eine (Id. 53981) ligg på berg i dagen med moglegvis ein større stein i kvar ende i ein låg konstruksjon innved dyrka mark. Den andre ligg i dyrka mark på ein mindre bergknaus (Id. 71891) med synleg oppkasta stein. Begge har ei opplagt plassering for rydningsstein frå ei rydda flate, og begge ligg i den dyrka marka der museet undersøkte dyrkingslag i 2014 (Jensen et al., 2015). Her er den einaste konsekvente fellesnemnaren koplinga til gravområdet ved den gamle kyrkjestaden ca. $50-75 \mathrm{~m}$ lengre nord, som desse røysene er ein samanhengande del av. Denne koplinga har bestemt klassifiseringa som gravrøyser.

\section{Nyare undersøkingar av røyser - eit paradigmeskifte?}

Ved nyare undersøkingar av røyser utført av Arkeologisk museum, UiS, har ein funne materiale og konstruksjonsdetaljar som syner ein auka kompleksitet samanlikna med resultata frå tidlegare granskingar. Årsaka til det er at prosjektleiara har gått frå å ha eit funksjonelt fokus på sjølve røysa, til i staden å opne opp større flater, og dei har brukt annan gravemetodikk og andre dokumentasjonsmetodar, sjå f.eks. Dahl (2016) for utførleg skildring. Dette gjer at vi får ein større kontekst og kompleksitet ved undersøkingar enn tidlegare, då den sterkt avgrensa dokumentasjonen kom fram ved avdekking for hand (Fig. 6).

Ei samanstilling av undersøkingar i Rogaland dei seinaste åra - frå Øvre Øksnavad, Orstad, Skadberg og Tjemslandsmarka - løyser opp stereotypane for kva som er ei gravrøys og kva som er ei rydningsrøys. Vi har funne graver i lågt og fuktig terreng ved Tjemslandsmarka, saman med moglege rydningsrøyser eller røyser med lang brukstid og ulikt innhald frå ulike tidsperiodar.

På Øvre Øksnavad, Klepp kommune (Gil Bell \& Denham, denne antologien), ligg røyser etter ryddingar monumentalt plasserte oppe på menneskeskapte terrassar, graver finst i skråningar, rydningsrøyser er bygde om til graver, og graver har endra funksjon til rydningsrøyser. Der finst noko som mest kan samanliknast med ein brem på ein hatt: ei lang, smal steinpakning på ein av plassen sine menneskeskapte terrassar som omkransar ei av dei største gravrøysene frå bronsealderen. I denne steinbremmen er det bygd inn gravrøyser, og der finst gravrøyser med store jordfaste steinblokker, noko som stereotypane seier er identifikasjonen på rydningsrøys. Det siste var også tilfellet ved Orstad, der brente menneskebein vart funne (Bjørdal \& Rødsdalen, 2015). På ein av Øvre Øksnavad sine terrassar ligg røyser saman med andre strukturar, som stolpehol til hus og kokegroper. Røysene som er plasserte inne i denne steinbremmen på Øvre Øksnavad liknar eit fenomen 

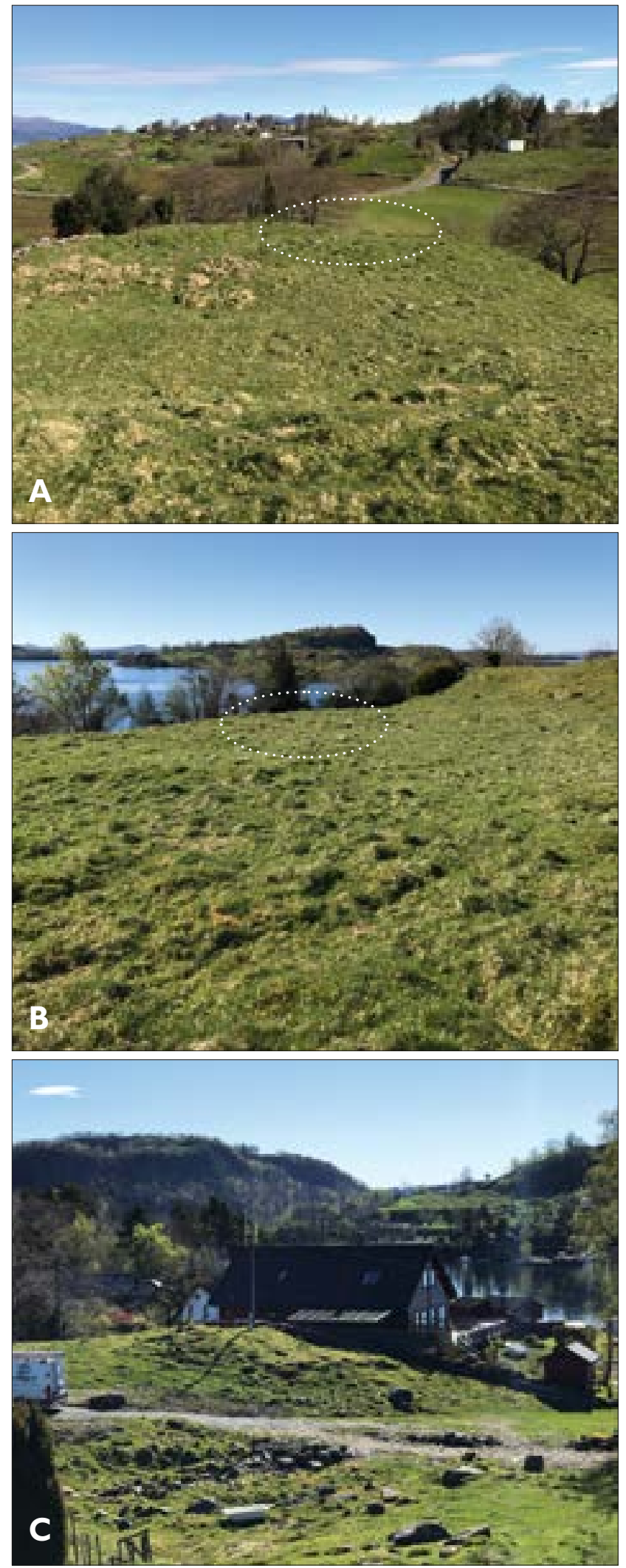

Fig. 5. A) Id. 71897 sett mot nord frå høgda; B) Id. 44239 sett mot sør-sørvest og C) Id. 34199 med flaggstong sett mot aust frå Id. 71897. Alle fotos: Håkan Petersson

Fig. 5. A) Site Id. 71897 seen towards the north; B) Site Id. 44239 (in the foreground of the picture) seen towards south-southwest and C) Site Id. 34199 with a flagpole on it seen towards the east from site Id. 7I897. All photos: Håkan Petersson

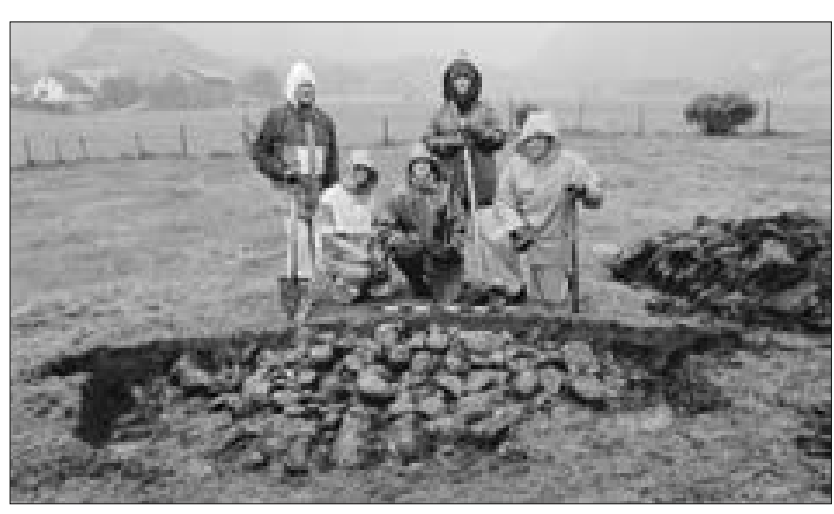

Fig. 6. Eksempel på tidlegare undersøkingsmetodikk av røyser, der ein tek torva av med hand og granskar eit sterkt avgrensa areal (frå Forsandundersøkingane på 1980-talet). Foto: AM/UiS Fig. 6. Example of an earlier documentation method for cairns, stripped by hand and with a very restricted investigation area (from the "Forsand investigations" of the 1980s). Photo: AM/UiS

frå Bohuslän i Sverige, der steinpakningar er med å viske ut eller skjule røyser (Lindqvist \& Toreld, 2010; Munkenberg, 2012; Svensson, 2015).

På Orstad, Klepp kommune (Bjørdal, 2017 og denne antologien), i eit steinfelt på ein skråning finn vi fleire utydelege og synleg fragmenterte røyser utan klare avgrensingar bygde av eit variert steinmateriale, blant anna kring jordfaste blokker. Dei oppfyller alle stereotypane for rydningsrøyser, men likevel er nokre av dei, i det minste delvis, brukte som graver eller til gravlegging, mens andre har uavklart status.

På Skadberg, Sola kommune, finst tre nærast runde røyser og ei med svært usymmetrisk form, som alle er plasserte i eit steinbelte i ei skråning. Ein del stein er tydeleg sortert og arrangert (Husvegg et al., 2017, s. 65-64). Som Fig. 7 viser, har røys 1 strukturelle element som finst i både gravrøyser og rydningsrøyser. Ho ligg topografisk i tråd med stereotypen for plasseringa av rydningsrøyser, men har eit relativt stort funnmateriale, blant anna skår frå minst tolv leirkar og ein flateretusjert pilspiss av rhyolitt tilverka med ein teknikk som normalt ikkje vert brukt på denne typen råmateriale.

På Tjemslandsmarka i Hå kommune (Fig. 8) vart tolv røyser i eit felt, som i utgangspunktet var registrert som eit rydningsrøysfelt, undersøkte med ein metodikk som om dei var graver (Bortheim \& Dahl, 2014). To av røysene vart klassifiserte som sikre graver (R5200 og R5333, Bortheim \& Dahl, 2014). Ei av dei andre røysene som er klassifisert som usikker grav, meiner eg har tilstrekkelege indikasjonar når det gjeld konstruksjonselement til å vere ei sannsynleg grav (R6066). Dei andre er klassifiserte som usikre graver eller som rydningsrøyser. På plassen finst også anlegg i form av ardspor, groper, eldstad, grøfter og 44 stolpehol. Dei påviste stolpehola utgjorde ikkje spor etter 


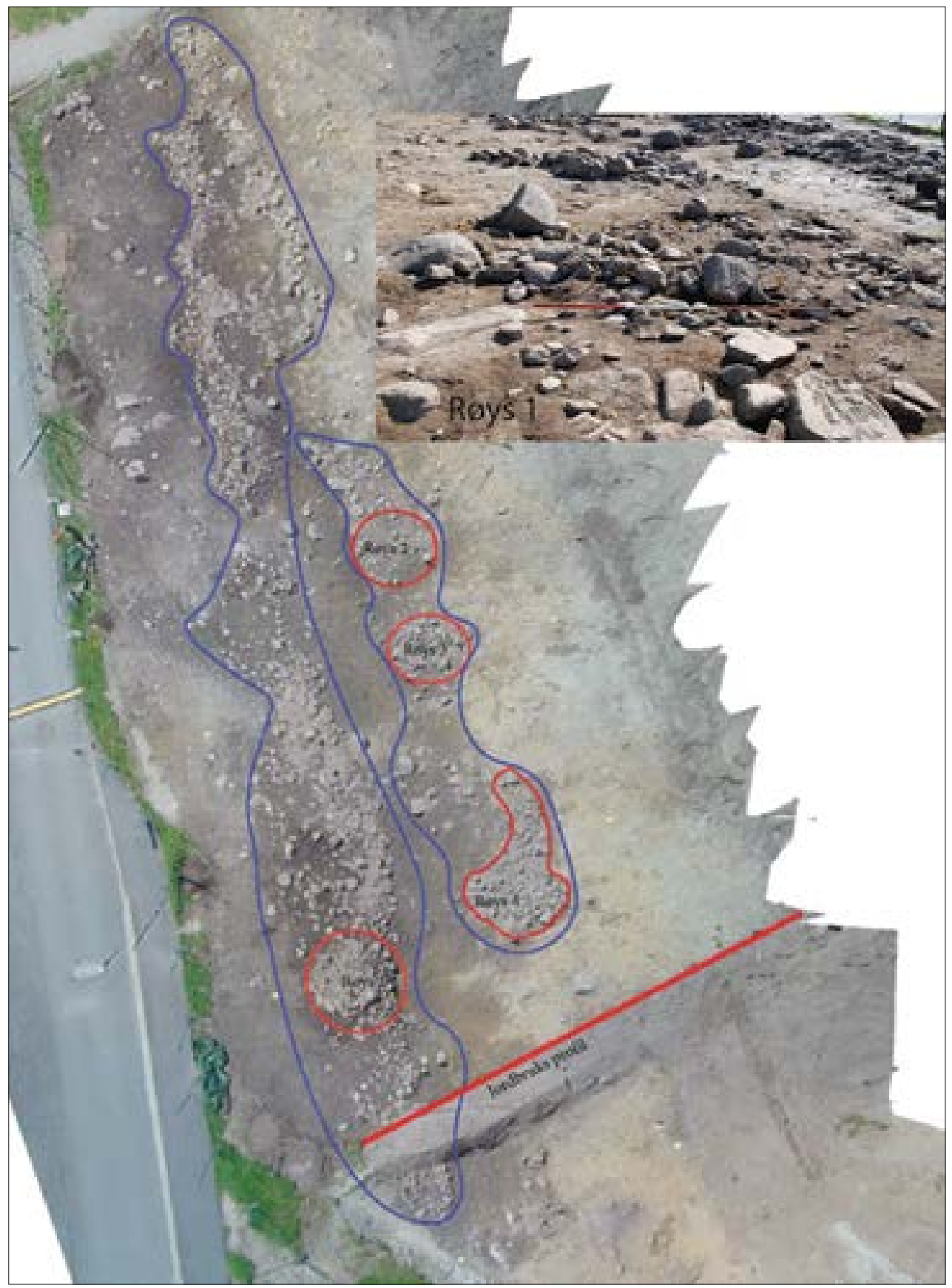

Fig. 7. Røyser og steinbelte på Skadberg, Sola kommune (Husvegg et al., 2017).

Fig. 7. Cairns and stone belt at the Skadberg site, Sola municipality (Husvegg et al., 2017).

nokon klar huskonstruksjon. Graver og rydningsrøyser ligg såleis saman i topografiske plasseringar, der graver etter stereotypane ikkje skal finnast. Feltet inneheld eit stort tal røyser som det ikkje var tid til å undersøke, då tidsbruken opphavleg var berekna ut frå at det dreidde seg om eit rydningsrøysfelt. Undersøkingane måtte difor avgrensast til eit utval røyser, som vart granska stratigrafisk for å sjå om dei kunne vere graver. Dette var eit klokt grep av prosjektleiar Barbro Dahl, fordi vi fekk eit resultat som viser kompleksiteten som ligg i røysundersøkingar. Men mykje gjekk samstundes tapt. Mellomliggande område er ikkje undersøkte, og andre tolkingsdefinisjonar enn rydningsrøyser - respektive gravrøyser - er ikkje vurderte. Vi har ikkje heile konteksten, og kanskje kan mykje av området ha hatt mange forskjellige tydingar og ulikt innhald for menneska i forhistoria når det kjem til funksjon og førestillingar.

Eksempla viser at dei tradisjonelle kriteria for røyser ikkje held stikk, og på bakgrunn av observasjonane frå Sjernarøyane meiner eg at vi ikkje kan vite noko om funksjon og innhald av ei røys før vi har undersøkt ho. Dermed er ikkje oppdelinga av desse synlege kulturminna i rydnings- og gravrøyser hensiktsmessig i forvaltninga. Det skapar problem heller enn svar og løysingar, særleg da budsjettet for undersøking av rydningsrøyser ofte er mykje mindre enn for gravrøyser. 


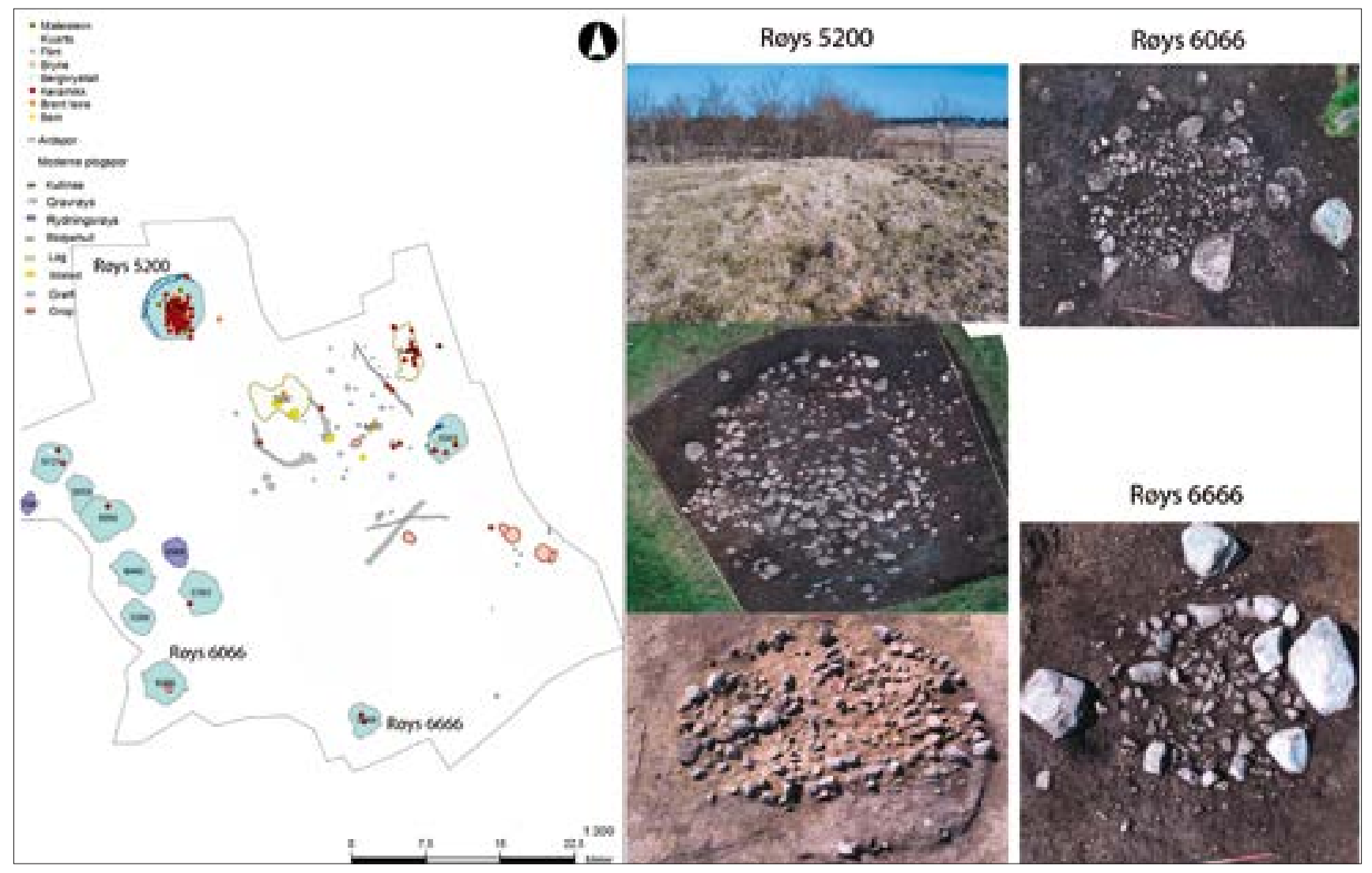

Fig. 8. Oversikt av undersøking på Tjemslandsmarka, Hå kommune (Bortheim \& Dahl, 20l4).

Fig. 8. An overview of the excavation of the Tjemslandsmarka site, Hå municipality (Bortheim \& Dahl, 20/4).

\section{Røyser som handlingar av kulturelle prosesser}

På det Småländska höglandet i Sverige finst nokre av dei største røysområda i Skandinavia (Fig. 9). Andre område i Skandinavia med store røysfelt er Östergötland, Uppland og Bohuslän. Interessant i denne samanhengen er at det i Sverige er gjennomført mange og store forvaltningsundersøkingar av rydningsrøysområde dei siste ti åra, som har gjeve mykje ny kunnskap. Samla viser dei at slike felt kan bestå av ei rekkje ulike kulturminne. Rydningsrøyser, gravrøyser, moglege gravrøyser og komplekse røyser finst saman med steinstrengar, steinpakningar, hus og andre strukturar som groper, eldstader, kokegroper, dyrkingslag osv. (f.eks. Torstendotter Åhlin, Skoglund, Cronberg, Gustafsson \& Högrell, 2002; Torstendotter Åhlin, Skoglund, Engman, Lagerås, Linderoth, Regnell \& Svanberg, 2003; Häggström, 2005, s. 65-144; Munkenberg, 2012; Petersson, 2015). Desse og andre undersøkingar vitnar om stor kompleksitet og variasjon av menneskeskapte konstruksjonar av stein.

Kvernsteinar i graver blir tolka som ein representasjon av koplinga mellom liv og daude, fruktbarheit og avling. På det Småländska höglandet finst dei i både graver og definerte rydningsrøyser på same felt (Häggström, 2005, s. 121-123, 133; Petersson,
2015, s. 87), mange gonger saman med skålgroper og funn av keramikk og vekstar. På Öggestorp (Fig. 9) var dodre (Camelina sativa) og korn medvite lagt ned i ei rydningsrøys (Häggström, 2005, s. 129-135). Undersøkingar viser også korleis rydningsrøyser/komplekse røyser/røyser utan grav er tydeleg strukturerte og i større grad bygde med eit formål, som meir enn røyser av «oppkasta stein» (bl.a. Häggström, 2007, s. 34; Wangen, 2009; Petersson, 2015; Lönn, denne antologien). Ved å gå frå berre å undersøke einskilde røyser til å flateavdekke rydningsrøysområde har det tydeleg vorte dokumentert at agrarhistoriske objekt, som for eksempel rydningsrøyser, mange gonger har eit kontekstuelt forhold til fornminnekategoriar som graver, hus og andre strukturar. Ut frå dette kan ein slutte at dei synlege agrarhistoriske objekta berre er indikasjonar på ein mangslungen bruk av eit samansett kulturlandskap.

Steinpakningsbrem eller store samanhengande steinpakningar på gravfelt og buplassar, slik som på Skadberg og Øvre Øksnavad, er også vanleg å finne ved store forvaltningsundersøkingar i Sverige der ein flateavdekker eit område. Der har dei oftast ingen synlege gravleggingar og få andre synlege strukturar, men ein tydeleg relasjon til andre delar av kulturmiljøet, for eksempel 


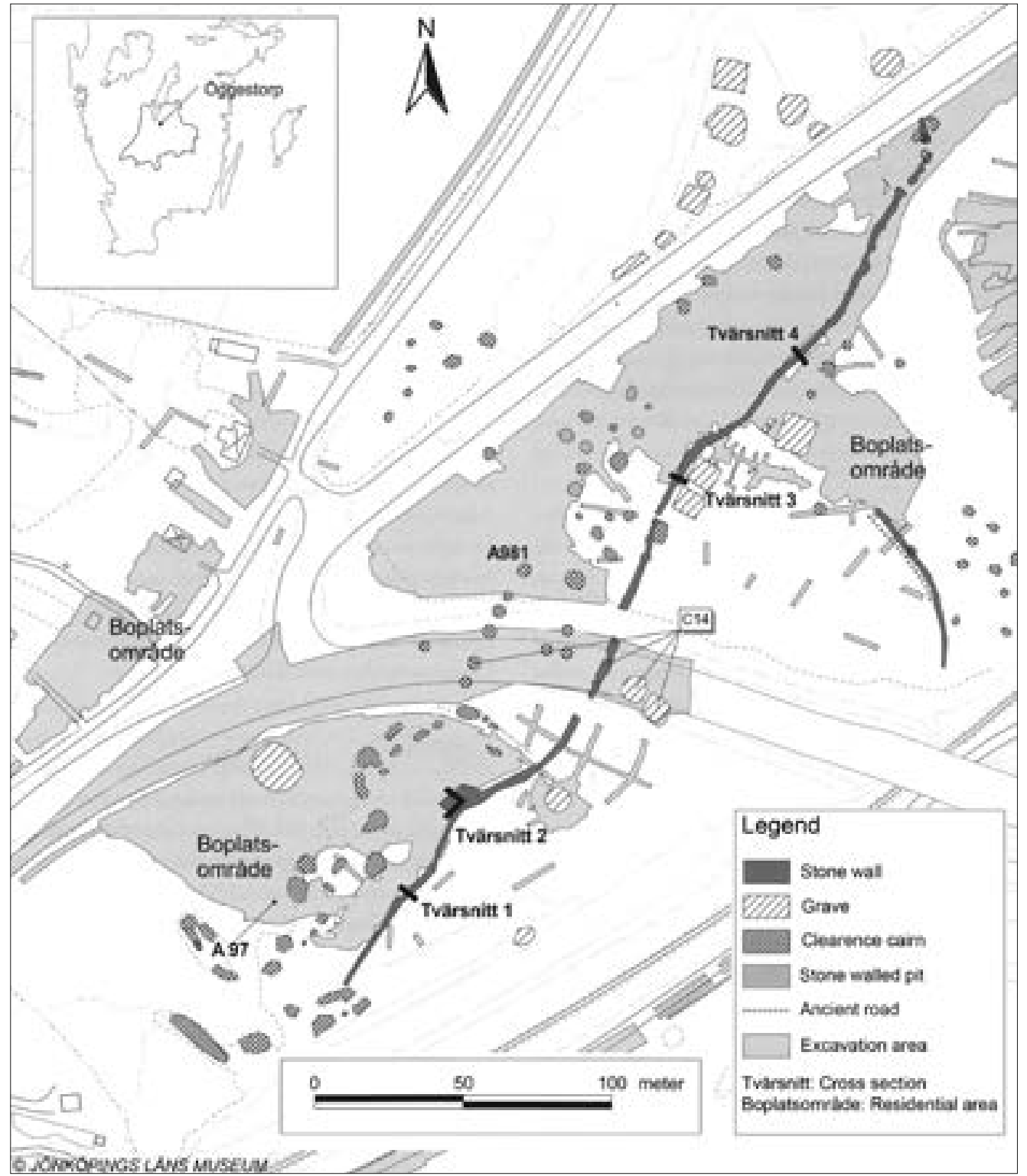

Fig. 9. Oversikt over undersøkingane av Öggestorp-komplekset på Småländska höglandet, Sverige (Häggström 2007).

Fig. 9. An overview of the investigations at the site complex at Öggestorp, in the highlands of Småland county, southern central Sweden (Häggström 2007). gravfelt eller einskilde graver (Munkenberg, 2010, 2012; Lindqvist \& Toreld, 2010; Lönn, 2015; Svensson Hennius, 2015; Lönn, denne antologien). Slike steinpakningar kan liggje som sjølvstendige strukturar som på Tanum 539, Bohuslän (Svensson Hennius, 2015), eller medvite kle inn og drapere graver, som om ein ynskte å viske dei ut i landskapet som på for eksempel Foss 239, 438, Bohuslän (Munkenberg, 2010, s. 249-250). Somme stader ser det ut til at steinbremmar berre er konstruksjonar i seg sjølv og har ein eller annan meiningsberande funksjon (Munkenberg, 2012; Svensson Hennius, 2015). I andre tilfelle finst det steinstrenger mellom eller ved sida av røyser. Det siste har vi døme på både frå Norge og Sverige (Løken, 1974, s. 24; Pettersen \& Sheen, 1976; Dommasnes, 1997; s. 110, 164-165; Häggström, 2005, s. 129-131; Lindqvist \& Toreld, 2010, s. 275; Munkenberg 2010, s. 242). I Vest-Sverige finn vi gravfelt som ligg på bergimpediment innved dyrka mark, i kontekstar som tidlegare vart tolka som rydningsrøyslokalitetar (Lindqvist \& Toreld, 2010, s. 273-274).

Det mest uttalte eksempelet på å leggje stein er eit særleg vestsvensk fenomen, der ein har valt å kle inn eit berg med stein, såkalla «stenklädda berg» (Lönn, denne antologien). Det finst parallellar også i AustSverige, men dei ser litt annleis ut. Grunnfunksjonen er at berg er fylt igjen, bygd på og forma om med stein, og mange gonger saman med funndeponi, kulthus og graver (Karlenby, 2015; Lönn, 2015).

«Det är svårt att förstå dessa stenklädda berg och bergskanter och omflyttandet av sten i naturliga stensamlingar på annat sätt än kultiskt. Sten och berg hade också en plats i föreställningsvärlden och det finst flera exempel på kopplingar mellan sten/berg och kult» (Lönn, denne antologien). 
Anja Mansrud har ved ei undersøking på Gvarv, Telemark, i 2015 (denne antologien) funne ei omarbeidd gravrøys, der også gjenbruk av flint frå steinalderen er eit element. Det same fenomenet med gjenbruk av funn frå steinalder i røyser, steinkledde berg og steinpakningar førekjem i det vestsvenske materialet (Hernek, 2015).

Undersøkingar som desse viser kor feilaktig det er å sjå ei rydningsrøys berre som ei rydding av eit område for å dyrke mark. Dette er kanskje den primære, funksjonelle grunnen til skapinga av røysene, men likevel meiner eg dei må ha hatt ei djupare meining og tyding i agrarsamfunna. I nokre tilfelle held dikotomien rydningsrøys - gravrøys ikkje stikk, men er viska ut med usikre typar, mellomtypar, røyser som er både og, røyser som er noko anna - ikkje heilt likt - eller er røyser som endrar innhald og meining over tid. Rydningsrøyser kan vere enkle objekt, små ubetydelege ting som er blitt konstruerte ved eit enkelt tilfelle, men dei kan sannsynleg også vere resultat av prosessar og langvarig bruk, som har skifta meining og innhald gjennom fleire hundreår.

Samstundes har definisjonen av «grav» blitt utvikla. Som undersøkingane frå Øvre Øksnavad viser, er det svært få gravleggingar i røysene. Røysene vert difor definerte som graver meir ut frå konstruksjonsdetaljar, og i nokre tilfelle frå enkelte funn i dei. I så måte er Øvre Øksnavad-feltet berre ein masse stein. Likevel har undersøkingane gjeve mange nye og interessante data. Funnmangel har utvikla metodikk og prøvetaking og ført til nye måtar å undersøke på, noko som framleis vil kunne gje mange nye svar og nye spørsmål. Indikasjonar på det har vi ikkje berre frå Øvre Øksnavad, men også frå undersøkinga av Tjemslandsmarka.

Tal frå Sverige vitnar om ein generell mangel på gravlegging i røyser. I Foss sokn i Bohuslän finst gravlegging i 11 av 64 definerte gravrøyser, og ei liknande samanstilling frå Göteborg tilseier at berre 50 prosent av undersøkte røyser inkluderte gravlegging (Andersson, 1982; Lindqvist \& Toreld, 2010). Mange gonger blir røyser også i Sverige kategoriserte som rydningsrøyser, eller stensättningsliknande röjningsrösen, primært fordi gravlegging saknast i skriftlege skildringar (Munkenberg, 2010, s. 243-244).

Uansett om vi berre definerer røyser som enkle rydningsrøyser, er det grunn til å tru at dei har hatt ei meiningsberande betyding i landskapet og kan gje oss meir samansett informasjon om forhistoriske samfunn. Men det føreset at vi reviderer gravingsmetodikk og omfanget av undersøkingar, og ser røysene i kontekstuell samanheng med det større kulturlandskapet dei ligg i. Samansette komplekse landskapshistoriske system med store røysfelt som på Småländska höglandet (Häggström, 2005, s. 65-103), har vi i Rogaland færre av. Øvre Øksnavad representerer likevel ein kompleksitet av strukturar når det gjeld røysfelt. Vi har i Rogaland kanskje aldri hatt undersøkingar av så store areal som i Öggestorp. Men samstundes kan det stillast spørsmål ved om vi eigentleg har søkt etter denne typen komplekse system av strukturar og kulturminne på røysfelta våre. Forskinga verkar lenge å ha vore tydeleg fokusert på sjølve objektet, det vil seia røysa, og først i seinare tid har synet på desse røysmiljøa som hendingar av komplekse prosessar vorte utvikla (f.eks. Dahl, 2016). Det er ikkje lenge sidan vi berre torva av røysa for hand og slutta når steinen slutta. Men samstundes, i eit fullåkerlandskap kor stein er rydda inn i moderne tid, er den slags forhistoriske steinkonstruksjonar og komplekse system av andre strukturar ikkje å finne igjen på markoverflata. Det er gjennom å grave sjakter rundt, mellom og utanfor dei synlege strukturane at vi vil kunne endre biletet. Då vil både andre former for strukturar og eit auka tal med røyser/røysrestar kome for dagen. Øvre Øksnavad viser korleis sjakting auka talet røyser med ca. 25 prosent, frå 79 til over 100 .

Ein endra måte å undersøke og tolke strukturar, særleg røyser, vil kunne hjelpe oss til å revurdere mange av dei eldre granskingane. Eit døme er Gauselundersøkingane, som er kjende for rike våpengraver og ei båtgrav. I eit lite område midt blant desse fanst røyser som vart definerte som rydningsrøyser, berre fordi dei ikkje hadde tilstrekkeleg med funn og var for omrota til å bli klassifiserte som graver. Likevel inneheldt somme av desse konstruksjonsdetaljar som moglege heller, enkelte brente bein, ei samanbretta bronseplate og eit skar frå leikar. Røysene hadde eit omfang på 3-5 m, var 0,5 m høge og av uformeleg til «tilnærmet» rund form (Børsheim \& Soltvedt, 2002, s. 217-219). Alle røysene, grav- som rydningsrøyser, verkar å ha lege på ei menneskeskapt forhøging av den opphavlege markoverflata (Fig. 10). Er dei graver eller rydningsrøyser, eller begge delar?

\section{Ei røys er aldri berre ei røys}

Sett i relasjon til den kompleksiteten vi finn i ulike steinkonstruksjonar, blir definisjonen rydningsrøys versus gravrøys nærast utan meining når vi skal forstå samfunnsaktivitetar. Røysene har eit djupare meiningsberande element og tyding innanfor samfunnsideologien og førestillingsverda som vi må prøve å fange opp med ei meir open haldning til kompleksiteten. Vi må komme bort frå arkeologiens historisitet om å sjå 


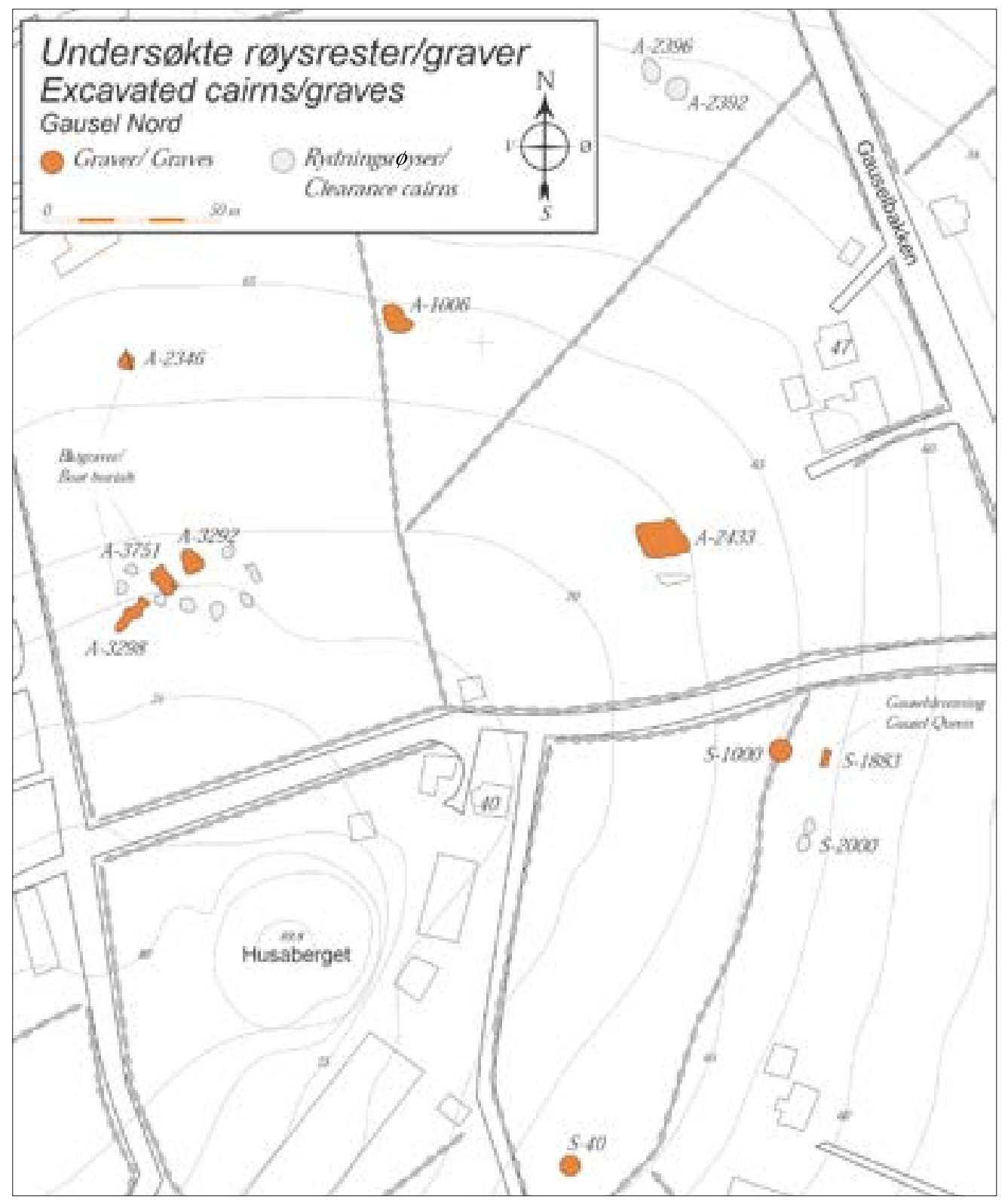

Fig. 10. Plan over Gauselundersøkingane (Børsheim \& Soltvedt, 2002). Fig. 10. Plan over the Gausel excavations (Børsheim \& Soltvedt, 2002). røyser som einskilde objekt i landskapet, for i staden å sjå dei som restar av ulike hendingar og prosessar med lang brukstid. Det vil skape større kompleksitet i tolkingar, som kan føre kunnskapstilveksten framover og inn på heilt nye tankebanar og analysar enn tidlegare. Ein må endre tenkemåte og utvikle nye måtar å dokumentere på. Ved å stille spørsmål ved definisjonen av ei røys vil vi også utvikle nye typar og former av steinbygde strukturar i vårt ynske om å skape meining og forståing av forhistoriske samfunn. Kunnskapstilveksten er altså også ei utvikling av arkeologien. Alt er visst nok ikkje det same som for 50 år sidan.

Resultat frå seinare års forvaltningsundersøkingar ulike stader i Skandinavia viser at rydningsrøyser også har eit potensial i arkeologien til å vere meir enn berre eit arkiv av botaniske data. Saman med andre agrarhistoriske strukturar - som syner kontinuitet, brot og omfang av dyrking - men også som del av ein kontekst med funn av andre arkeologiske spor på plassen, er dei ein viktig del av forståinga vår av kulturlandskapet. Desse aspekta kjem tydelegare fram i lyset ved at vi erkjenner kompleksiteten i røysfelt, der røysene ser ut til å ha kunne skifte meining og innhald over tid. Det er prosessen, bruksfasar og brukstid saman med korleis plassen vert brukt, som kan vise til kompleksitet og tyding av dei i samfunnet, kulten og kosmologien eller den rolla dei har spela i næringsstrategiar. Det er først etter avdekking vi byrjar å skjønne oppbygging og samanheng som røysfelta og dei enkelte objekta med ein eller annan form for sikkerheit kan definerast ut frå. Forvaltninga burde ta omsyn til dette og gjere fleire registreringar og undersøkingar, 
men ikkje minst bevare rydningsrøyser som synlege kulturminne på same måte som vi bevarer synlege gravminne.

\section{Credo}

Eg meiner at implikasjonane av den argumentasjonen eg har lagt fram, må vere at røyser som fysiske objekt bør omtalast for kva dei er, utan eit tolkande prefiks, fram til dei blir undersøkte; det vil seia berre ei røys. La oss oppvurdere røyser frå berre fysiske objekt, og la oss sjå dei som resultat av komplekse prosessar med ulike bruksfasar, meiningar og innhald over tid, men også som indikasjonar på mykje anna aktivitet som ikkje syner på markoverflata. Samla vil dette bidra til betre kunnskap om dei forhistoriske samfunna og menneska sine handlingar.

Å halde fram å vurdere røyser ut frå tradisjonelle arkeologiske definisjonar av grav eller rydding gjev eigentleg fleire spørsmål enn svar. La i staden hendingane røysa er ein del av, tolkast ved ei undersøking. Ved registrering eller liknande beskriv kulturminnet og den kompleksiteten det har, slik ein betre kan evaluere potensialet, heller enn å prøve å definere funksjon og underforstått kor viktig røysa er.

Noverande syn på rydningsrøyser som enkle og mindre viktige objekt, som lett kan frigjevast og ikkje treng å undersøkast i så stor grad, burde vere historie. Definerte rydningsrøyser bør vurderast frå tilfelle til tilfelle og ut frå tidlegare kunnskap om dei, region for region. Undersøkingar frå andre stader viser at store rydningsfelt kan ha eit rikt og variert informasjonspotensial med liknande kompleksitet som gravfelt. Å konsentrere undersøkinga til å snitte ei rydningsrøys for å ta prøvar vil difor redusere dette potensialet. A ikkje ha eit totalperspektiv på røysproblematikken, kan det sjåast som god forvaltningspolitikk? Og oppfyller det eit grunnleggande krav til vitskapleg dokumentasjon?

Som eg har prøvd å argumentere for, og andre forskarar som Hansson (2008) tidlegare har peika på, så finst det ikkje nokre klare røyskategoriar. Det er denne kompleksiteten som er interessant å undersøke, uansett om det er graver eller agrarhistoriske objekt. Eg meiner at verdiane til dei ulike røystypane ligg i den dokumentasjonen vi kan få ut av det enkelte kulturminnet og kringliggjande område, med grunnlag i dei vitskaplege spørsmåla som vi stiller til dei aktuelle undersøkingane. Føremålet med undersøkingar kan - og bør - difor variere ut frå aktuelle problemstillingar med grunngjeving i kvalitet, omfang, bevaringsgrad osv.

Difor må også tydinga av kompleksiteten, og ikkje minst den faglege verdien av registrerte agrarhistoriske kulturminne, oppvurderast, om vi skal kunne utvikle kunnskapen. Men også definisjonen av ei grav har vorte utvida, og omgrepet grav/gravlegging er ei tolking forskinga diskuterer med såpass breidde at ein kan byrje å spørje når ei røys blir ei grav. Mange av dei gravene vi finn i dag er utan grav/gravlegging, eit anlegg utan grav (Wangen, 2009). I staden bør vi opne opp for at det kan ha funnest andre typar av hensiktsmessig menneskeleg bruk av stein i forhistoria. I denne samanhengen er Vivian Wangens (2009) analysemetodikk, der ho konsekvent skil grav og gravlegging, metodologisk interessant. Ho ser hendinga i seg sjølv og objektet, dvs. steinkonstruksjonen med eller utan gravlegging, som eigne materielle uttrykk.

La oss byrje å sjå prosessar i staden for objekt i kulturminna. Eg trur at vi da vil opne opp for eit nytt informasjonspotensial i forskinga, også i dei no «mindre verdifulle» kulturminna, som rydningsrøyser. Ei slik tilnærming vil kunne bidra til å utvikle kunnskapen om forhistoria.

\section{Summary}

In Norway, stone cairns have traditionally been defined as either burial structures or clearance cairns (i.e. piles of stones accumulated during the clearance of soils for agricultural purposes), and rarely anything more. In fact, these are the only two existing categories available for defining cairns in the country's national cultural heritage register.

This article attempts to look beyond the traditional concept of cairns as physical objects, the results of specific activities and expressions of specific ideologies, viewing them instead as undergoing as continuous process of redefinition.

The cairns and cairn fields located on the Sjernarøyane group of islands, in the interior of the Boknafjord, Rogaland, are presented as a case study. The interpretations of these cairns have been re-evaluated in the light of recent research results. It is suggested that the traditional definitions and criteria are no longer appropriate and that a new perspective is required. Such a change could have significant implications for both cultural heritage management and research.

Cultural heritage management professionals in Norway have developed certain criteria for defining a cairn as a grave or a clearance cairn. Graves are seen as planned constructions with internal structure, while clearance cairns are piles of stones with no internal order. Graves are dominant features in the landscape, generally occupying higher ground with clear visibility of the surrounding area, while clearance cairns are seen as lying downslope or on lower parts of the terrain. Round, well-shaped cairns are graves, while those with oval or irregular shapes, sometimes located adjacent to larger boulders, are defined as clearance cairns. Size is also an important factor. Larger cairns (both in terms of height and diameter) are often seen as burials, while cairns which are lower and cover less area usually are defined as clearance cairns. Any cairn that cannot be definitively classified as either a burial or a clearance cairn according to these criteria 
are automatically categorized as clearance cairns, based on the idea that anything that cannot be positively identified as a burial, according to the established criteria, must be clearance cairns.

However, recent excavations and research from Rogaland (for example Bortheim \& Dahl, 2014; Husvegg et al., 2017; and Bjørdal as well as Gil Bell \& Denham, this publication)) illustrate the difficulties of defining cairns to one of the two cultural heritage management categories based on visual inspection. Very often, the initial categorization is incorrect, or the reality of the situation is more complex than the forced burial/clearance dichotomy suggests. Only excavation can clarify this, something that is not obvious from the categorizations presented in cultural heritage management documentation or taken into consideration at the legislative level.

To complicate the picture even further, many cairns, which should be classified as graves by virtue of their size or shape, are without finds, making it even more difficult to define them. Various excavation techniques and methods have been developed to help identify features, which may be associated with burial activities. As a result of these types of excavations, the word "grave" has come to be seen more than just a term used to refer to a single event, embodying a single ideology. It has come to be seen as part of larger, longer-term social processes, particularly regarding theories about ritual contexts, fertility cults and cosmology, and how these relate to prehistoric agricultural activities. So the question is in rescue excavations, can we treat the two categories of cairns differently without biasing our resulting understanding of cairns and their relevance to prehistoric society? In my experience dealing with this issue in the field of cultural heritage management, the answer is, to a certain extent, unclear.

This article argues from a smaller case study that we should not take these traditional criteria for defining cairns, particularly those for clearance cairns but also those for burial cairns, for granted. Many of the clearance cairns in the national cultural heritage register could, by combining the lessons learned from recent excavations with earlier knowledge, just as easily be categorized as possible graves. When deciding which heritage sites to remove in advance of development, grave cairns are usually preserved while clearance cairns are excavated and removed. Clearance cairns are also generally permitted to be excavated using less time consuming, less thorough and less expensive methodologies.

Current cultural heritage management practice therefore risks missing important features and evidence associated with clearance cairns in comparison with grave cairns. By moving towards a single-context approach, disregarding whether the cairn has been defined as a grave or a clearance cairn, in combination with excavating larger areas around the cairn itself, a better understanding of the complexity of the processes represented in the cairn has developed.

The field of cultural heritage management should therefore move away from the above-mentioned criteria for categorizing cairns as either burial or clearance, and towards a single category, which avoids assumptions regarding function. The use of a single category would ideally limit bias when evaluating the status of monuments and planning/ budgeting for their possible removal. The current evaluation process, as I have tried to stress, is based on definitions in the national register, definitions which modern research either contradicts or at the very least highlights the uncertainty of.

There are numerous examples across Scandinavia, which show these clearance cairn fields as complex cultural phenomena, cultural sites connecting agriculture activities to ritual and cosmology. These fields are very often hiding several different types of archaeological structures, processes and site types. The complexity of agrarian societies and the close connection between farming practices, rituals and cosmology can be reflected in the physical rearranging stones in the landscape to form structures. The most developed ideological use of stones is perhaps from western Sweden, the so-called "stone-paved mountain" sites (Lönn, this publication). These are the result of a longue dureé of building and re-shaping the landscape by different human activities all connecting ritual, burial and profane activities. The same is seen in grave fields located on mountains, where the stones seem to have been used to erase the visual aspects of the burial-cairns (Lindqvist \& Toreld, 2010; Munkenberg, 2012; Lönn, this publication).

This article puts forward the suggestion that cultural heritage management professionals should re-evaluate/upgrade the scientific value of clearance cairns, and the importance of agricultural features in general. These are more than mere examples of prehistoric agriculture. They are critical to our understanding of the complex social systems they represent, for example the importance of fertility-cults to early agricultural societies. Developing a stronger appreciation of the information potential in these types of monuments and planning/excavating accordingly, will provide a more comprehensive understanding of these structures, and how closely the daily life of prehistoric societies was intertwined with food strategies, rituals and cosmology.

We also need to reflect upon the consequences of this in the legislative management of cultural heritage, when it comes to both decisions regarding preservation or excavation of these types of heritage sites, and the scale, cost and scientific demands of these excavations. Who knows what would result if we began investigating areas of defined clearance cairns with the same ambition and intensity as we do when excavating burial cairn fields, rather than merely focusing on the visible clearance cairns?

Ignoring the broader perspective of cairns and the problems associated with their categorization within cultural heritage legislation is no longer good heritage management policy. It barely fulfills the basic requirements of scientific documentation demanded by the Cultural Heritage Act, the Valetta convention and so on. Recent excavations have shown the need for a revitalization of cultural heritage legislation, in accordance with new research. If research does not ultimately feedback into cultural heritage management, then why do we have it in the first place?

\section{Litteratur}

Andersson, S. (1982). Rösen och stensättningar $i$ Göteborg undersökta 1960-1970 (Fyndrapporter 1980-81).

Göteborg. Göteborgs Arkeologiska museum.

Bjørdal, E. \& Rødsdalen, S. (2015). Arkeologisk undersøkelse 
av røysfelt fra bronse- og jernalder på Orstad gnr. 9, bnr. 8 og 15, Klepp k., Rogaland (Oppdragsrapport 2015/10). Stavanger. Universitetet i Stavanger, Arkeologisk museum.

Bortheim, K. \& Dahl, B. (2014). Arkeologisk undersøking av røysfelt fra E.BRA og bosettingsspor fra FØRROM $i$ Tjemslandsmarka. Tjemsland Nordre gnr. 53, bnr. 1 og 68, Hå kommune, Rogaland (Oppdragsrapport 2014/2). Stavanger. Universitetet i Stavanger, Arkeologisk museum.

Børsheim, R. L. \& Soltvedt, E. -C. (2002). Gauselutgravingene 1997-2000. AmS-Varia 39. Stavanger.

Dahl, B. (2016). Haugen som gravfelt. I W. Brun \& E. S. Pedersen (Red.), Tverrfaglige perspektiver 3, (s. 77-96). AmS-Varia 58. Stavanger.

Dommasnes, L. H. (1997). Tradisjon og handling i førkristen vestnorsk gravskikk. Undersøkelser på et gravfelt på Vereide i Gloppen, Sogn og Fjordane (Arkeologiske rapporter 21). Bergen: Arkeologisk institutt, Universitetet i Bergen.

Holm, I. (1995). Trekk av Vardals agrare historie. Varia 31. Oslo: Kulturhistorisk museum, Fornminneseksjonen.

Hansson, M. (2008). En gammal grävning, ett kulthus och ett antikvariskt problem. I M. Hansson, \& J. Goldhahn (Red.), Gropar E monument. En vänbok till Dag Widholm. Kalmar: Högskolan i Kalmar.

Hernek, R. (2015). The flints of the ancestors. I H. Petersson \& C. Toreld (Red.), Domestic life in the Tanum rock carving area. Settlements, graves and rituals in the vicinity of the world heritage rock carvings of Tanum, s. 243-257. Uddevalla. Kulturhistoriska dokumentationer nr. 29, Bohusläns museum förlag.

Husvegg, J, Soltvedt, E. -C. \& Dahl, B. (2017). Arkeologisk og naturvitenskapelig undersøkelse av røyser fra E.BRA og hus fra Y.ROM ved Skadberg skole (id. 157229 og 65854): Skadberg gnr. 32 bnr. 19, Sola kommune, Rogaland (Oppdragsrapport 2017/1). Stavanger. Universitetet i Stavanger, Arkeologisk museum.

Häggström, L. (2005). Landskapsutnyttjande, bete och odling på Sydsvenska höglandet under järnålder, exemplet Öggestorp (Doktorgradsavhandling), GOTARC. Series B. Gothenburg Archaeological Theses. No 34, Göteborgs universitet og Jönsköpings läns museum, Jönköping.

Häggström, L. (2007). Monument eller liklös grav? I L. Häggström (Red.), Öggestorp \& Rogberga: vägar till småländsk förhistoria. Jönköping. Jönköpings läns museum.

Jensen, C., Ahlquist, J. \& Fredh, D. (2015). Stratigrafisk undersøkelse av forhistoriske kulturlag på Eik, Sjernarøyene (Oppdragsrapport 2015/11). Stavanger. Universitetet i Stavanger, Arkeologisk museum.

Karlenby, L. (2015). Mytisk geografi och landskapets outömliga variation. In Situ Archaeologica, vol. 11, 43-53.

Lindqvist, M. \& Toreld, C. (2010). Det mångfacetterade sakrala landskapet. I H. Petersson \& C, Toreld (Red.),
Utblickar från Munkedal. 10000 år av bohuslänsk förhistoria (s. 25-279). Uddevalla. Kulturhistoriska dokumentationer nr. 27, Bohusläns museums förlag.

Løken, T. (1974). Utgraving på gravfelt ved Løvik, Aukra, Møre og Romsdal (Rapport, Arkeologisk serie 1974:7). Oslo. Det kgl. Norske Videnskabers Selskab, Museet.

Lönn, M. (2015). Sten och eld. Kulthandlingar på berget i Stora Holm. In Situ Archaeologica, vol. 11, 25-41.

Munkenberg, B. -A. (2010). Fyra bronsåldersgravfält i Tanum och Foss socknar. I H. Petersson \& C. Toreld (Red.), Utblickar från Munkedal. 10000 år av bohuslänsk förhistoria, s. 236-254. Uddevalla. Kulturhistoriska dokumentationer nr. 27, Bohusläns museums förlag.

Munkenberg, B. -A. (2012). Stenpackningar. Lämningar efter många företeelser och fenomen. In Situ Archaeologica, vol. 10, 39-67.

Petersson, M. (Red.). (2015). Farstorp - ett röjningsröseområde i långtidsperspektiv: Småland, Nässjö kommun, Barkeryds socken, Kramsäng 1:2 och 1:11 samt Ryssby 2:11, RÄ̈ 287, 295, 358, 362, 363, 364, 371: arkeologisk undersökning (UV Linköping rapport 2015:116). Linköping.

Pettersen. K. \& Sheen, R. 1976. Fortsatt utgraving, 1975 og 1976, på gravfeltet ved Ingridsteinen, Løvik, Aukra, Møre og Romsdal (Rapport, Arkeologisk serie 1976:1). Oslo. Det kgl. Norske Videnskabers Selskab, Museet.

Svanberg, F. (2000). Gravar i röjningsröseområden. De förmodade gravarna inom Hamneda RAÄ 77 och problematiken kring röjningsröseområden och gravar i södra Sverige. I P. Lagerås, L. Högrell, P. Skoglund \& I. Torstensdotter Åhlin (Red.), Arkeologi och paleoekologi $i$ sydvästra Småland: tio artiklar från Hamnedaprojektet, s. 113-133. Lund. Riksantikvarieämbetet. Malmö. Arkeologiska undersökningar skrifter No 341.

Svensson Hennius, J. (2015). All these stones. I H. Petersson \& C. Toreld (Red.), Domestic life in the Tanum rock carving area. Settlements, graves and rituals in the vicinity of the world heritage rock carvings of Tanum, s. 189-213. Uddevalla. Kulturhistoriska dokumentationer nr. 29, Bohusläns museum förlag.

Torstensdotter Åhlin, I., Skoglund, S., Cronberg, C., Gustafsson, P. \& Högrell, L. (2002). Boplatslämningar och röjningsrösen, Småland, Ljungby kommun, Hamneda socken, RÄ̈ 66, 67, 76 och 82. UV Syd rapport 2002:3). Lund. Riksantikvarieämbetet.

Torstensdotter Åhlin, I., Skoglund, P., Engman, F., Lagerås, P., Linderoth, T., Regnell, M. \& Svanberg, F. (2003). Arkeologisk undersökning. Gravar, röjningsrösen och boplatslämningar. Småland, Ljungby kommun, Hamneda socken, RAÄ 77 (Smålands museum rapport 2003:42). Jönköping.

Wangen, V. (2009). Gravfeltet på Gunnarstorp i Sarpsborg, Østfold. Et monument over dødsriter og kultutøvelse $i$ yngre bronsealder og eldste jernalder. Norske Oldfunn XXVII, Oslo. 